not on "congestion of the brain," or the liver, the kidneys, or spleen? I should like to see an answer to this.

Another view of the case might have suggested itself. Did the girl Greener not die from the shock of the surgical operation rather than from the effects of the chloroform? I would strongly recommend Sir John Fife and Dr. Glover to peruse Mr. 'Travers' work "On Constitutional Irritation," wherein, after his excellent remarks on the subject, he relates several cases of death while the patients were on the operating table. Indeed, every one knows that hundreds of deaths have occurred while the patients were under the operator's knife. A case of this kind happened in the Edinburgh Hospital towards the end of last harvest, a woman having died while being operated on for hernia, without ether.

Thousands have inbaled chloroform without a single fatal result up to the present alleged case. Reasoning from analogy, then, the death in this case was more likely caused by the shock to the system than by the inhalation of the chloroform vapour.

Dr. Simpson's reasons for supposing asphyxia the cause of death are unanswerable, and put the matter heyond a doubt; but I have been induced to make these few remarks to show that on no consideration should death have been attributed to "congestion of the lungs from chloroform."

Medrcus.

\section{TOE-NAIL OPERATION SUCCESSFULLY PERFORMED UNDER THE INFLUENCE OF CHLOROFORM.}

To the Editor of THE LANCET.

Sin,-The unfortunate case of death from the use of chloroform, reported in one of your late numbers, having forcibly arrested public as well as professional attention, I have been induced to transmit you the following case, more by way of counteraction to the impression imparted by such an occurrence, than from any peculiarity presented in its features.

A farmer's daughter, aged seventeen, living at Dinckley, Ribblesdale, had long suffered from disease of the great toe-nail. She says that it commenced two years ago, and she has never lain in bed for the last six months, owing to the pain at night being so extremely acute. She preferred sitting in a chair al night, with the diseased foot generally resting on the cold floor.

On visiting her, I found her general health much impaired; pulse 96 ; tongue white and dry; face pale and haggard; legs immensely swollen, owing apparently to her confined and constantly sitting posture. In short, there was much constitutional irritation, without any obvious visceral disease.

Every application had been tried to heal the sores without any effect. The second great toe also was beginning to be very painful, from the same disease.

After a short trial with various constitutional remedies, and seeing no prospect of any success, I proposed the evulsion of both nails, and promised to give her chloroform. Dr. Irving and Dr. R. T. Martland, of Blackburn, met me in consultation, and it was decided that the operation should be performed as soon as possible. Sunday, the 6 th of February, was fixed upon.

I may here state, that the first time I learned anything about the fatal case at Newcastle happened on the previous Saturday evening, whilst looking over the pages of THe LANCET; and the two cases proving almost identical in character and features, I must confess that the reading of it impressed me with certain misgivings as to the result, and in which feeling, I suspect, my two medical friends participated. However, the operation was performed. About five drachms of chloroform was expended on the handkerchief, the patient being so agitated as greatly to resist the inhalation.

The success was everything that could be wished, and the sores have assumed a very healthy aspect. She slept soundly in bed the first night after the operation, and has no particular wish as yet to encounter the risks of her former posture. The swelling of the legs has subsided, and her spirits are quite revived, and she hopes she may be permitted to take "the sleeping stuff" again, should any other operation on her person ever become necessary.-Yours most obediently,

Ribblesdale, Lancashire. RIChaRd Hindle, M.D.

\section{SALARIES OF ASSISTANTS TO POOR-LAW MEDICAL OFFICERS. \\ To the Editor of 'THE LANCET.}

Srr,-A great deal has been lately said respecting the inadequate remuneration of Poor-law surgeons, and every unprejudiced man mustallow, very properly; but nothing has been said to promote the benefit of that ill-used class, - medical assistants, - on whom generally the onus of attending the Unions is thrown by their employers, who requite their hard services with the footman's usual wages of thirty pounds a year. It would be well if Poorlaw medical officers and others would approach nearer home, and ask themselves-A re they acting justly in giving to those who assist them a salary so very disproportionate to the labour? This is an abuse which ought to be remed:ed, and as long as it remains as it is, will be a disgrace to the profession.

I am, your very obedient servant,

A SUFferer.

\section{THE NATIONAL ASSOCIATION AND NATIONAL INSTITUTE.}

To the Editor of THE LANCET.

Sin,- Whatever may be said by others regarding the National Association, the hole-and-corner gentry of our diploma-selling medical bodies may well exclaim, somewhat like the owl in the Eastern fable, "God bless the National Association; so long as it continues we sha'n't want for ruined doctors." Since the establishment of this Association, the corporate bodies, whose Augean stables are yet uncleansed, have enjoyed a state of repose to which they had been strangers for many years.

When the National Association was formed, upwards of three years since, the glorious cause of medical reform, to which you and your fellow reformers had devoted your lives, was all but triumphant; the profession were aroused to its necessity, the press supported it, the public advocated it, and her Majesty's Government had interposed to accomplish it.

At that moment the National Association took the good canse in hand; and what has been the result? Let the profession answer in your columns.

The medical corporate bodies have again gained strength and confidence, and proceed in their old course of taking care of themselves, but of nobody else; they have lost all that apparent fear and trembling which denoted a foregone conclusion, and proceed now, afraid and ashamed of no one, not even of themselves.

The medical profession were elate with the prospects of victory already all but in their grasp, and joyfully awaited the establishment of a body which would yield to them some protection, some support, some shelter,- to which they might refer when oppressed by Boards of Guardians, or otherwise ill-treated; but alas! their joy has been turned to despair,- - their confidence has been betrayed,- their money has been spent; and the Burkers of medical reform remain unpunished.

Not content with thus strangling medical reform, they must interpose in every effort on the part of the profession to emancipate themselves, and shake off the galling fetters which an inhuman law, created by inhuman monsters, has imposed upon them. A Poor-law Union Medical Association is formed, the National takes it under the shadow of its wing, and spreading its upas poison around, extinguishes it for ever!

To whom are we to ascribe the disgraceful treatment of Dr. Berncastle, and the thousand others who have been equally illtreated? To the National Institute!

Another Association has been formed at the East-end of London, for mutual protection; pray recommend them to the National Institute.

What have we now, in return for our exertions, our confidence, our money? A nominal Assaciation, which exists only in name and in its spirit of evil, with a perpetual president, perpetual secretaries, and something like a perpetual committee, all of whom will doubtless continue until Messrs. Snipe and Sneak find a better berth for themselves, unless the profession grow wise in time, and stop the supplies.

Put your Herculean shoulders to the wheel once more, and the incubus will be cast off. We are not yet, Promethean-like, bound to a rock, that this bird of prey may feed on our vitals with impunity.- Your obedient servant,

\section{A Member of the Nationat Association.}

SUGGESTION TO USE ELECTRO-GALVANISM IN THE SYNCOPE FOLLOWING THE ADMINISTRATION OF CHLOROFORM.

\section{To the Editor of THE LANCET.}

SrR,-I was somewhat surprised to find that Dr. Simpson, from his being practically so well acquainted with the properties and power of the electric fluid, in commenting on Mr. Meggison's fatal case after the inhalation of chloroform, did not most strongly recommend the immediate use of electro-galvanism, in addition to withdrawing the handkerchief or inhaler from the mouth, the admission of free air, and the sprinkling of the face with cold water, (see The LaNCET, No 1276, p. 176.) Having 
now for many years tried electricity, and proved its powerful remedial agency in various diseases, $I$ can most conscientiously advise its use in any future unfortunate case of anæsthesia that may occur, as well as in the asphyxia that follows an overdose of prussic acid, and also in narcotism following the abuse of opium, or any other vegetable poison.

In either case, so confident am I of its power and efficacy, that I should feel myself very uncomfortable had I not a machine, and an efficient one, at hand, to fly to immediately in case of an untoward accident.-I am, Sir, your obedient serrant,

Princes-street, Coventry-street. J. H. Horne, Surgeon.

\section{TESTIMONIAL TO DR. BERNCASTLE.} To the Editor of The Lavoet.

SrR,-I beg, through the medium of your columns, to call on the profession generally to subscribe, for the purpose of presenting to Dr. Berncastle a testimonial expressive of our sympathy in his cause, and our disgust at the conduct of the coroner, jury, and guardians.

I shall be happy to receive subscriptions from gentlemen in my neighbourhood, and will set down, as a commencement, $£ 5$, for myself and two friends. I propose that the sum collected be presented to Dr. Berncastle in the form of a purse, to be by him laid out as he may think fit.

In making this appeal to my professional brethren, I trust I need not remind them that it is their duty and interest both, to rally round an injured member of their community, for what is his lot to-day, to-morrow may be their own.

I am, Sir, your obedient servant

Lewisham, Feb. 1848 C. Wilson Steel.

\section{FRIGHTFUL MORTALITY AMONGST MEDICAL PRACTITIONERS IN IRELAND.}

PROPOSALS FOR THE SUCCOUR OF THEIR FAMILIES.

To the Editor of THE LANCET.

Srr,-I sincerely trust that the melancholy details which you have given of the truly frightful mortality among our professional brethren in Ireland during last year, have been perused with thoughtful attention by every reader of your widely-circulated journal. One in abont every fourteen of the nedical practitioners of that country swept off in the course of twelve months !- a rate of mortality greatly exceeding the average in the unhealthiest climates in the world. That the fatal fever was, in almost every instance, caught from attendance upon the sick, is just what we might have expected; nor can any one wonder at the frequency of this result, if he will but realize to his mind for a moment the condition of a man, worn out, it may be, at the time with fatigue and anxiety, visiting the wretched inmates of an Irish hovel,-the very focus of destitution and filth at the best of times. I verily believe that there is not a spot on the face of the wide world where medical practitioners have to undergo such exhausting and unremunerative toil, and are exposed to greater danger in the discharge of their holy mission-that of ministering to the diseased-than in many of the districts of Ireland, where fever is epidemic through the land. Not to allude to other distressing circumstances in their position, I see it mentioned by Drs. Cusack and Stokes that the residences of the practitioners are sometimes so far apart from each other, that when one of our brethren has been himself overtaken with the pestilence, he has actually died without having received any professional attendance! When we learn at the same time that a family is thereby, in very many instances, left utterly unprovided for, must not the feeling of a strong sympathy at once take the place of a mere regret? Let the reader but look back at that account of destitution and suffering in some of the families, which you have given from the Report of the $\mathbf{M e}$ dical Temporary Relief Committee, and I am sure that his heart must burn with in him to do something to mitigate such distress. Ought we not, as a body, (I speak to my professional brethren in every part of the United Kingdom,) to inquire into the state of things as represented in that Report, in order that steps may be taken to afford assistance to the bereaved sufferers? There is a "Benerolent Fund Society" in Dublin, presided over and conducted by the leading physicians and surgeons of Ireland, the object of which institution is to relieve medical men under severe and urgent distress, occasioned by sickness, accident, or any other calamity; but the means at their disposal are utterly inadequate to the end in view. That most energetic friend of his brethren, Mr. Wilde, has, in the last number of the Dublin Quarterly Journal, appealed to the profession generally in aid of the Society at the present time. Now might we not make it the almoner of our bounty? - and as its active members have an exact acquaintance with the real condition of every applicant, we should have the satisfaction of knowing that the funds committed to their care would be faithfully and judiciously applied.

I could have wished much that some prominent and influential member of our ranks had taken up this subject, so that a prompt and efficient response might have been anticipated to the suggestion thrown out. I cordially hope, however, that my humble attempt may not have been made altogether in vain ; and in conclusion beg to say, that nothing will give me greater pleasure than to work with and under any gentleman or body of gentlemen who may think that my services can be of any use in promoting the good cause.

February, 1848 .

Gavin Mrlrox, M.D.

\section{POOR-LAW MEDICAL RELIEF,-LORD ASHLEY'S RESOI,UTIONS.}

To the Editor of The LaNCET.

SiR,-In your last two numbers of THE LANCET I find Lord A shley is about bringing certain resolutions before the House of Commons, respecting the poor-law medical officers, nearly all of which are very old, and have been in operation for years-I may say all, except that part relating to their salaries. In March, 1842, certain orders were issued by the Poor-Law Commissioners, and article twenty related to the medical officer's permanent appointment, \&c. My appointment was conferred in that year. Consequently, I am now appointed for life, or until I resign, or am disqualified. In June, 1847, a fresh number of orders were issued, and article 191 still further confirms article twenty, in 1842. Consequently, I do not see that Lord Ashley is going to do such great things for us, $-\mathrm{I}$ am, Sir, yours, \&c.,

a Union Medical Officer of Twelve Years' Standing.

\section{To the Editor of The LANCET.}

Sin,-In reference to the resolutions about to be submitted to the House of Commons for the medical treatment of the poor, by Lord Ashley, I beg to observe that the fifth resolution excludes members of the College of Surgeons unless they possess also a public medical degree or licence. Consequently, the great majority of the medical officers of the army and navy would be excluded from those civil appointments when they may retire from the service; as the diploma of the College of Surgeons, though indispensable, is the only collegiate qualification required from candidates for public employment, yet they are also required to produce testimonials of adequate medical studies in all branches of the profession, and to undergo examinations before the respective Boards; yet they could be objected to, notwithstanding their practical experience, and their acquired acquaintance with sanitary measures, so strictly enforced in the public services. This in itself would be a hardship to the medical officers, and probably an injury to the public; but it would, moreover, by implication, prove a serious detriment to retired officers entering private practice, as the question might be asked-" How can you consult an army doctor? they are not fit or qualified men to attend the poor!"

I would, then, hope that members of the College of Surgeons, having served in the army or navy for five years, may be included in the fifth resolution as competent persons.

Douglas, Isle of Man, Feb. 1848.

Yours, \&c.,

L. $\mathrm{S}$.

\section{NEW MEDICAL REGISTRATION COMMITTEE.- THE NATIONAL INSTITUTE. To the Editor of THr Lavcet.}

Sir,-It is with feelings of infinite pleasure that I read in your journal of last week of the nomination of the members of the new committee for inquiring into that perplexing subject, medical reform, or better regulation of the medical profession. Sincerely do I hope, and am confident I do not by any means stand alone in my desire, that ere this session of Parliament shall have passed away, your untiring endeavours and zeal for the great body of surgeons, civil, naval, and military, will ultimately produce some permanent benefit to all. Much as there is to contend with, nothing seems to me so absurd as the striving of a body, self-styled the National Institute, and whose actions are continually receiving wholesome reproof from your powerful pen. That their boastings about head and home can have any operation upon the legislature, I cannot for one moment conceive; or that the House of Commons can believe that they are the representatives of that great body, the English surgeons, is too ridiculous for me to entertain the slightest idea. There are enough medical corporations now for granting degrees, and ascertaining the fitness of candidates to practise the science of medicine, and the several branches of knowledge connected with 